\title{
NEW UROCOPTID LAND SHELLS FROM MEXICO
}

\author{
By Paul Bartsch \\ Curator, Division of Mollusks, United States National Museum
}

During his recent botanical explorations in Mexico, Mr. C. R. Orcutt was good enough to collect a large series of mollusks, which has resulted in quite a number of sendings from various stations visited by him. Among the material which has thus accumulated in the National Museum are a lot of Urocoptid mollusks in need of names which are here supplied. It should be remembered that No. 2594 of the Proceedings of the United States National Museum (volume 67 , article 22 , pages 1 to 5 , with one plate), published in 1925, was based on one of the early sendings of this expedition. In this, Holospira (Holospira) orcutti, Holospira (Holospira) monclovana, and Holospira (Eudistemma) picta were described as new.

\section{HOLOSPIRA (COELOSTEMMA) BALSASENSIS, new species}

Plate 1, fig. 16

Animal pale brownish ashy. Shell cylindro-conic, thin, horn colored, semitranslucent. Nuclear whorls 3, strongly rounded, forming an almost cylindric apex, flattened at the top. The nuclear whorls are marked on the early turns by a finely granular sculpture only, while toward the end, the rib sculpture of the postnuclear turns, slowly and feebly encroaches upon them. Postnuclear whorls well rounded, marked by numerous rather strong, somewhat distantly spaced axial ribs which are particularly conspicuous on the slowly increasing cone of the shell, while on the middle turns they become somewhat enfeebled, again increasing in strength on the last two whorls. Suture conspicuously constricted. Periphery of the last whorl well rounded. Base short with a very narrow slitlike umbilicus. The last portion of the last whorl is solute, and on this the axial ribs become much reduced and irregular, closely spaced, and extend all around the whorl. Aperture moderately large, subcircular, the parietal wall portion flattened; peristome slightly expanded and slightly reflected. When the shell is ground down, the pillar is seen 
to increase in size toward the apex and becomes very much contracted in the last turn. There is a slight twist a little nearer the base of the whorls than the middle. The pillar also is marked axially by slender retractively slanting threadlike riblets. There are no lamellae.

The type (Cat. No. 363129, U.S.N.M.) was collected by C. R. Orcutt at Balsas Station, Guerrero, Mexico. It has 19.5 whorls, and measures-length, $21.9 \mathrm{~mm}$.; diameter, $5.5 \mathrm{~mm}$.

The type, plus 99 topotypes (Cat. No. 363130 U.S.N.M.), yield the following measurements:

\begin{tabular}{|c|c|c|c|}
\hline 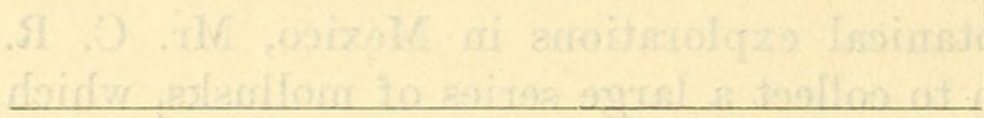 & $\begin{array}{l}\text { Number } \\
\text { of whorls }\end{array}$ & Length & Diameter \\
\hline $\begin{array}{l}\text { Greatest_. } \\
\text { Least_.. } \\
\text { A verage... }\end{array}$ & $\begin{array}{r}20.1 \\
14.8 \\
17.3\end{array}$ & $\begin{array}{l}22.3 \\
15.6 \\
19.2\end{array}$ & $\begin{array}{l}6.0 \\
4.9 \\
5.5\end{array}$ \\
\hline
\end{tabular}

HOLOSPIRA (COELOSTEMMA) ADRIA, new species

Plate 1, fig. 1

Shell small, pupoid. Nuclear whorls 2.3, strongly rounded, the first $1 \frac{1}{2}$ forming a cylindroid apex with a truncated top, the last one increasing materially in size. The nuclear whorls are finely granulose; the last half of the last turn shows an encroachment of the axial rib sculpture of the postnuclear turns upon it, but this is much enfeebled. The first two postnuclear whorls increasing rapidly in size, form with the nuclear turns a broad conic apex; the major portion of the postnuclear whorls form an almost cylindric spire, the greatest diameter being reached on the fifth whorl after which the diameter of the spire becomes slowly contracted. The early postnuclear whorls are marked by coarse, strong, retractively slanting axial riblets, while on the middle whorls these riblets become about doubled in number and much finer and less strongly developed. On the last turn they again become more distantly spaced and heavier. Suture strongly impressed. Periphery of the last whorl obscurely angulated. Base short, well rounded, narrowly perforated. The last portion of the last whorl is solute. On this the axial ribs become much enfeebled, closer spaced, irregular and irregularly crowded. They extend all around this portion. Aperture subcircular; parietal wall flattened; peristome slightly expanded and reflected. In the ground-down specimen the hollow pillar is shown to increase steadily in size from the anterior to the posterior end of the shell, becoming very much expanded in the apical whorls. In the last whorl it is slender. The pillar is marked by numerous lines of growth and rather feebly developed axial threads. There are no spiral lamellae. 
The type (Cat. No. 363131 U.S.N.M.) was collected by C. R. Orcutt in river drift near Rio Balsas Station, Guerrero, Mexico. It has 14 whorls, and measures-length, $10.9 \mathrm{~mm}$.; diameter, $4.6 \mathrm{~mm}$. A paratype (Cat. No. 363132 U.S.N.M.) has 16.7 whorls, and measures-length, $14 \mathrm{~mm}$; diameter. $4.5 \mathrm{~mm}$.

HOLOSPIRA (COELOSTEMMA) ADANA, new species

Plate 1, fig. 14

Shell cylindro-conic, horn colored. Nuclear whorls 2.6, well rounded, all but the last half marked by fine granules only. On the latter there are slender retractively slanting axial riblets. Early postnuclear whorls forming a narrow cone, well rounded, the middle ones moderately rounded, marked by numerous retractively slanting aixal riblets which are a little more distantly spaced and a trifle stronger on the cone than on the middle, but only a very little so. On the last whorl they become very strong and distantly spaced. Suture moderately constricted. Periphery well rounded. Base short, rimate, strongly rounded, marked by the continuations of the axial ribs which extend into the umbilical chink. Last whorl solute with an obsolete angle at the posterior angle of the aperture and an even less conspicuous one at the junction of the inner and parietal wall, marked behind the peristome by closely spaced axial riblets which extend all around the turn. Peristome expanded and somewhat reflected. The internal pillar rather stout, increasing in width posteriorly, hollow, marked by slender lines of growth and threadlike axial riblets.

The type (Cat. No. 363133 U.S.N.M.) was collected by C. R. Orcutt in river drift near Rio Balsas Station, Guerrero, Mexico. It has 17.8 whorls and measures-length, $19.1 \mathrm{~mm}$.; diameter, $4.6 \mathrm{~mm}$.

Cat. No. 363134 U.S.N.M. contains 80 topotypes which yield the following measurements:

\begin{tabular}{|c|c|c|c|}
\hline 180 & $\begin{array}{l}\text { Number } \\
\text { of whorls }\end{array}$ & Length & Diameter \\
\hline $\begin{array}{l}\text { Greatest. } \\
\text { Least.... }\end{array}$ & \multirow{2}{*}{$\begin{array}{l}18.5 \\
13.0 \\
15.6\end{array}$} & \multirow{2}{*}{$\begin{array}{l}20.5 \\
13.9 \\
17.1\end{array}$} & \multirow{2}{*}{$\begin{array}{l}5.1 \\
4.3 \\
4.8\end{array}$} \\
\hline A verage & & & \\
\hline
\end{tabular}

HOLOSPIRA (COELOSTEMMA) IQUALAENSIS, new species

Plate 1, fig. 12

Shell large, cylindroid, thin, semitranslucent, bluish white. Nuclear whorls 2.8, strongly rounded, all but the last half of the last one finely granulose, the axial rib sculpture of the postnuclear turns encroaching upon the last half postnuclear turn, but the riblets 
are exceedingly poorly developed. The nucleus is flattened at the summit and gives to the apex a truncated appearance. The nuclear whorls plus the early postnuclear whorls increase regularly in size, forming a rather long, regularly conic apex. The middle portion of the postnuclear spire is almost cylindric, the whorls contracting but slightly from the eleventh, which is the broadest, anteriorly. The postnuclear whorls are marked by slender, well-developed, slightly curved, retractively slanting axial riblets, which on the conical portion of the spire are about one-third as wide as the spaces that separate them. On the middle turns these riblets become much more numerous, sinuous and retractively slanting. Here they are about half as wide as the spaces that separate them. On the last turn they again become somewhat strengthened, though not nearly as much so as on the early turns, and also a little more distantly spaced. Suture well constricted. Periphery of the last whorl obscurely angulated. Base well rounded, narrowly openly perforated. The last portion of the last whorl is solute, and here the riblets become decidedly irregular, closely spaced and crowded, encircling the entire outer surface of the turn. A perture rather large, subquadrate with the peristome reflected and expanded, particularly so basally; parietal wall sinuous.

The type (Cat. No. 363135 U.S.N.M.) was collected by C. R. Orcutt at Iquala, Guerrero, Mexico. It has 17.9 whorls and measures-length, $25.4 \mathrm{~mm}$; diameter, $7.3 \mathrm{~mm}$.

HOLOSPIRA (BOSTRICHOCENTRUM) EURYBIA, new species

Plate 1, fig. 2

Shell small, pupoid, bluish white, with the cone flesh colored. Nuclear whorls 2.2, well rounded, all but the last half marked with fire granules only. In the latter the beginnings of the axial ribs of the postnuclear spire make their appearance. The postnuclear turns form a broad cone which extends over the first four turns at the end of which the greatest diameter is reached, and the rest of the postnuclear spire begins to slowly contract. The early postnuclear whorls are moderately rounded and marked by strong, rather distantly spaced curved axial riblets. The middle whorls have the riblets a trifle less strong and a little more closely spaced, while on the last turn the riblets become stronger and again more distantly spaced. Suture well marked. Periphery of the last whorl obtusely angulated. Base short, strongly curved, rimate, marked by the continuations of the axial ribs. The last whorl is solute for a little distance, with a strong angle behind the posterior angle of the aperture and a less strong one at the junction of the inner and parietal wall. The solute portion is marked by ribs which are scarcely diminished 
in strength, and encircle the entire whorl. Aperture subtriangular, peristome expanded and reflected. The internal pillar is rather thick, but decidedly reduced at the last whorl, with a strong fold which reaches its highest development in the penultimate turn and slowly diminishes posteriorly.

The type (Cat. No. 36147 U.S.N.M.) was collected by C. R. Orcutt in river drift near Rio Balsas Station, Guerrero, Mexico. It has 12.2 whorls, and measures-length, $11.5 \mathrm{~mm}$.; diameter, $4.5 \mathrm{~mm}$.

HOLOSPIRA (TRISTEMMA) MELEA, new species

Plate 1, fig. 11

Shell small, soiled white with the apex pale brown. Nuclear whorls $2 \frac{1}{2}$, well rounded, forming a conic spire, all but the last half whorl smooth excepting fine granules; the latter, however, has feeble retractively slanting irregular riblets. The early postnuclear whorls form a rather slender cone, all moderately well rounded, the first marked by rather strong, retractively slanting, axial ribs which become obsolete shortly after leaving this whorl, reappearing again as low, rounded, almost vertical, distantly spaced ribs on the last turn. Suture moderately constricted. Periphery well rounded. Base short, well rounded, narrowly umbilicated, marked by the continuations of the axial ribs. The last whorl is solute for a little distance, and bears a strong angle behind the posterior angle of the aperture. The solute portion is marked by slender, closely spaced axial riblets which encircle the whorl. The aperture forms a decided angle at the posterior angle; parietal wall somewhat sinuous, outer lip slightly expanded and slightly reflected. The internal axis is slender without fold in the last whorl. On the penultimate turn the parietal fold develops and reaches its maximum development although it extends into the antepenultimate whorl. At the penultimate turn also the basal fold reaches its fullest strength, but there is no indication of a labial fold.

The type (Cat. No. 363145 U.S.N.M.) was collected by C. R. Orcutt on the roots of orchids at Ixcaquixtla, Puebla, Mexico. It has 12.6 whorls, and measures-length, $13.9 \mathrm{~mm}$.; diameter, $4.2 \mathrm{~mm}$.

\section{HOLOSPIRA (BOSTRICHOCENTRUM) GALATHEA, new species}

Plate 1, fig. 6

Shell small, pupoid, milk white, excepting the cone which is flesh colored. Nuclear whorls 2.2, well rounded, all but the last half whorl marked by fine granules only. The beginning of the latter shows rather distantly spaced axial riblets. The postnuclear whorls form a broad cone, while the middle portion is cylindric. The whorls 
on the cone are moderately well rounded and marked by numerous retractively slanting axial riblets which increase in number and decrease in strength. On the middle portion of the spire these riblets become reduced and are almost obsolete. Suture well impressed. Periphery of the last whorl very strongly angulated. Base short, well rounded, narrowly openly umbilicated, last whorl not solute. Aperture subtriangular, peristome expanded and reflected. The internal pillar rather stout, decidedly attenuated at the last turn. There is a moderately strong fold in the penultimate whorl which extends feebly into the three whorls posterior to it.

The type (Cat. No. 363148 U.S.N.M.) was collected by C. R. Orcutt in river drift near Rio Balsas Station, Guerrero, Mexico. It has 12.2 whorls, and measures-length, $11.3 \mathrm{~mm}$.; diameter, $4.1 \mathrm{~mm}$. Cat. No. 363149 U.S.N.M. contains a paratype which is not quite perfect.

\section{HOLOSPIRA (TRISTEMMA) HYPERIA, new species}

Plate 1, fig. 15

Shell small, cylindro-conic, bluish white. Nuclear whorls 2.1, forming a rather broad apex, well rounded, marked by fine granules only. Postnuclear whorls forming a rather broad moderately long apex, the apical portion well curved and marked by rather strong, retractively slanting axial ribs which are a little less wide than the spaces that separate them. Beyond the cone these ribs become decidedly obsolete, reappearing only upon the last whorl where they are also only poorly developed. Suture rendered conspicuous by the somewhat overhanging tendency of the whorls. Periphery of the last whorl well rounded. Base short, well rounded, narrowly umbilicated. Last whorl not solute. Aperture moderately large, subtriangular, with a decided angle at the posterior angle. Internal axis moderately broad but decidedly contracted in the last turn, at the posterior extremity of which the parietal fold begins and extends up into the penultimate whorl, disappearing upon reaching the antepenultimate turn. The parietal fold and basal fold also attain their maximum development in the penultimate whorl. There is no indication of a labial fold.

The type (Cat. No. 363146 U.S.N.M.) was collected by C. R. Orcutt at Esperanza, Puebla, Mexico. It has 14 whorls, and measureslength, $13 \mathrm{~mm}$.; diameter, $4.3 \mathrm{~mm}$. Cat. No. 363147 U.S.N.M. contains two paratypes which are incomplete.

HOLOSPIRA (HOLOSPIRA) ALVAREZENSIS, new species

Plate 1, fig. 7

Shell small, cylindroid, pale brown. Nuclear whorls 3.1, large, forming a truncated cylindric apex. All but the last half of the 
last turn finely granulose. The latter shows the encroaching ribs of the postnuclear sculpture in an enfeebled state. Postnuclear whorls well rounded, increasing gradually in size, forming a very regular apical cone. The cone portion marked by rather strong retractively slanting axial riblets which are about one-half as wide as the spaces that separate them. In the central portion of the shell the whorls are crossed by rather flexuose, retractively slanting riblets which are much finer and a little more closely spaced than those on the cone. On the last two turns the ribs again increase in strength, becoming even a little stronger than those on the cone, but here they retain the flexuose aspect of the middle turns. Suture strongly constricted. Periphery of the last whorl rounded. Base short, well rounded, narrowly perforated. The last whorl is solute at its extremity and marked on the outside by riblets which are continuous all around, but here a little more closely spaced and less regular than on the preceding portion of the turn. Aperture subtriangular, the parietal portion being somewhat sinuous. Peristome continuous, expanded, and slightly reflected. In a ground-down specimen the pillar is found to be slender with a rather strong fold on the columella which extends through a little more than the last two whorls. The parietal fold is rather strong and reaches its greatest development in the next to the last turn where the basal lamella also is most strongly developed. Here, too, the short labial fold is present.

The type (Cat. No. 363136 U.S.N.M.) was collected by C. R. Orcutt near Alvaras, San Luis, Potosi, Mexico, at an altitude of 6,000 to 9,000 feet. It has 14.5 whorls, and measures - length, $10.7 \mathrm{~mm}$.; diameter, $2.5 \mathrm{~mm}$.

Eight additional specimens, paratypes, three of which are complete, yield the following measurements:

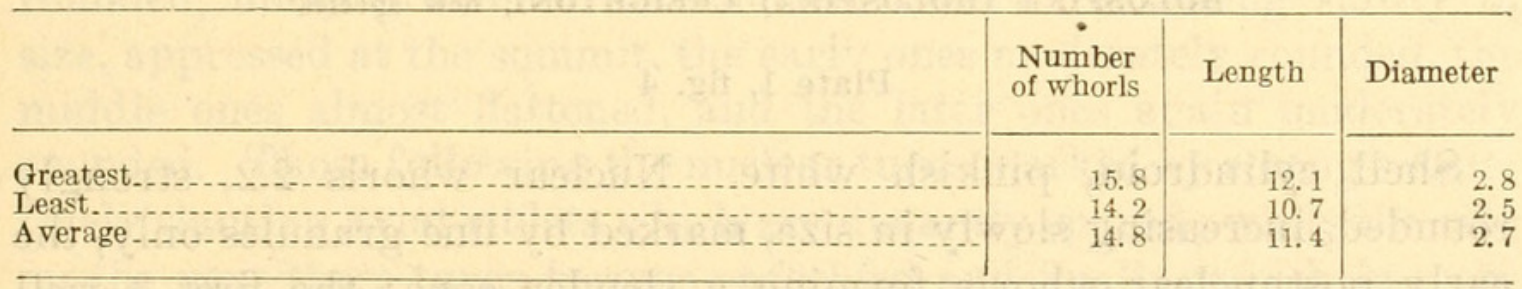

HOLOSPIRA (HOLOSPIRA) ANDROMEDA, new species

Plate 1, fig. 8

Shell of medium size, pale brown, with the ribs almost white. Nuclear whorls $23 / 4$, forming a conspicuous broad cylindroid apex. The nuclear whorls are well rounded, all but the last half of the last curn being granular. On the latter there are also feeble axial riblets which slowly increase in size toward the postnuclear spire. Postnuclear whorls increasing slowly in size, early whorls well rounded, marked by exceedingly strong lamellar, somewhat sinuous, retrac- 
tively slanting, axial riblets. On the middle turns these riblets become only a trifle less strong. On all the whorls they are less than half the width of the spaces that separate them. On the last two turns they again increase materially in size. Suture moderately constricted. Periphery angulated. Base short, almost flattened, narrowly perforated, marked by the somewhat enfeebled continuations of the axial ribs. The last portion of the last whorl is solute, and has the axial ribs encircling it as bands. On the extreme last portion, immediately behind the peristome, they become enfeebled and closely crowded. Aperture moderately large, subtriangular; parietal wall sinuous; peristome expanded and reflected. The internal pillar is slender, somewhat twisted, and in the last $31 / 2$ whorls there is a very strong submedian fold which reaches its highest development in the third to last turn. Here, too, the parietal fold reaches its greatest development. This is suspended vertically from the roof of the turn and its basal portion is bent outward almost at right angles to the main portion. The basal lamella, too, finds its greatest development in this turn, as does the labial fold.

The type (Cat. No. 363138 U.S.N.M.) was collected by C. R. Urcutt. Unfortunately no specific locality is cited. It has 17.4 whorls and measures-length, $13.5 \mathrm{~mm}$; d diameter, $3 \mathrm{~mm}$. Twentyfive paratypes (Cat. No. 363139 U.S.N.M.) are present, 9 of which are complete and yield the following measurements:

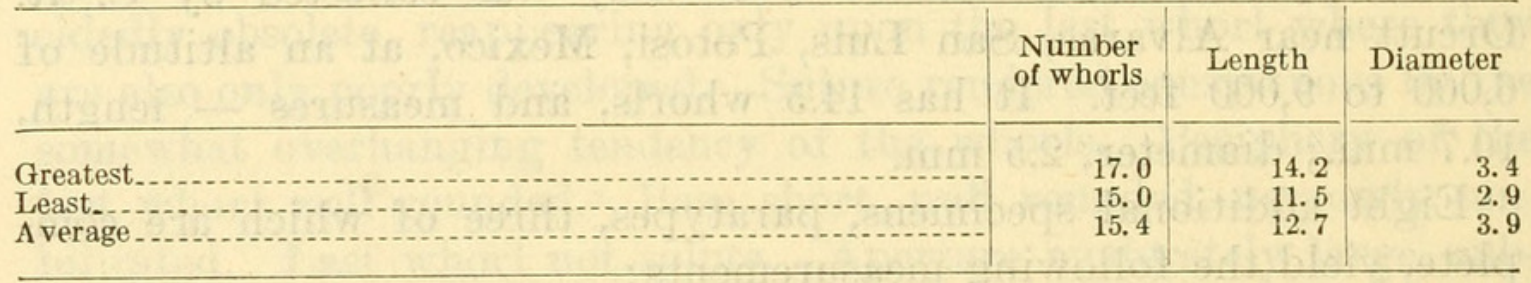

HOLOSPIRA (HOLOSPIRA) CREIGHTONI, new species

Plate 1, fig. 4

Shell cylindroid, pinkish white. Nuclear whorls 2.2, strongly rounded, increasing slowly in size, marked by fine granules only, the early postnuclear whorls forming a slender cone; the first 3 well rounded, marked by moderately strong, decidedly retractively slanting axial riblets, the rest almost smooth excepting the last $2 \frac{1}{2}$, on the first of which the ribs again become apparent, while on the last they are quite strong. The last whorl is decidedly attenuated anteriorly. Periphery rounded. Base short, narrow, well rounded, with an umbilical chink. The last portion of the last whorl is solute and bears a strong carina at the posterior angle of the aperture and an obsolete one at the junction of the inner lip and parietal wall. On this portion of the whorl the axial ribs are very much reduced, form- 
ing numerous closely appressed slender threads which have almost the appearance of lamellae. These threads encircle the entire whorl. Aperture subtriangular, peristome thin, expanded and reflected. The internal axis is moderately large and hollow; in the last whorl it is rather slender without even a twist. In the penultimate whorl a very strong fold develops on the middle of the pillar which almost disappears in the next whorl posterior to it. In the penultimate whorl also the strong parietal fold develops and reaches its maximum strength, almost disappearing in the whorl posterior to it. The same holds good of the basal fold. The parietal fold also is present in the penultimate whorl but not in the whorl posterior to it.

The type (Cat. No. 362178 U.S.N.M.) was collected by C. R. Orcutt on a hill east of San Pedro, San Luis Potosi, Mexico. It has 14.2 whorls and measures-length, $17.6 \mathrm{~mm}$.; diameter, $4.1 \mathrm{~mm}$.

Cat. No. 362179 U.S.N.M. contains 16 paratypes, 10 of which are perfect and yield the following measurements:

\begin{tabular}{|c|c|c|c|}
\hline 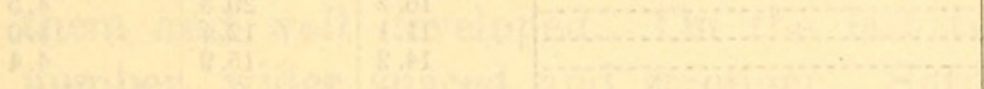 & $\begin{array}{l}\text { Number of } \\
\text { whorls }\end{array}$ & Length & Diameter \\
\hline reatest & $\begin{array}{l}14.5 \\
13.0 \\
13.7\end{array}$ & $\begin{array}{l}18.3 \\
13.7 \\
16.3\end{array}$ & $\begin{array}{l}4.1 \\
3.7 \\
3.9\end{array}$ \\
\hline
\end{tabular}

I take pleasure in naming this specimen for Thomas Creighton, to whom I am indebted for many hours of painstaking help in the preparation of material for description.

HOLOSPIRA (HOLOSPIRA) AMALTHEA, new species

Plate 1, fig. 13

Shell elongate-conic, pale brown. Nuclear whorls $2 \frac{1}{2}$, well rounded, finely granular. Postnuclear whorls increasing slowly in size, appressed at the summit, the early ones moderately rounded, the middle ones almost flattened, and the later ones again moderately rounded. Those following the nuclear turns marked by strong retractively slanting axial riblets which are distantly spaced; while the ribs on the next three turns become enfeebled and finally vanish in mere incremental lines. On the last whorl the ribs again appear, becoming fairly well developed on the later portion of the last turn. Suture well marked. Periphery of the last whorl obtusely angulated. Base short, well rounded, rimate, marked by the continuation of the axial riblets. Last whorl solute with a strong angle behind the posterior angle of the aperture and a lesser one at the junction of the outer and basal lip. The last whorl is marked behind the aperture by numerous closely spaced irregular axial riblets which completely encircle the whorl. Aperture broadly ear shaped, decidedly angulated at the posterior angle; outer lip broadly expanded and re- 
flected. The internal pillar very broad in the antepenultimate whorl and the one preceding it, narrowing posteriorly and anteriorly. In the last portion of the penultimate whorl the parietal fold begins to make its appearance and extends posteriorly for two turns, reaching its maximum development in the antepenultimate turn where also the parietal fold is present, strongly developed, and decidedly outcurved at its free margin. The basal fold here also is strongly developed as is the labial fold.

The type (Cat. No. 363140 U.S.N.M.) was collected by C. R. Orcutt at Monterey, Nueva Leon, Mexico. It has 15.3 whorls and measures-length, $16 \mathrm{~mm}$; d diameter, $4.3 \mathrm{~mm}$.

Cat. No. 363141 U.S.N.M. contains 31 topotypes, which yield the following measurements, and a number of fragments:

\begin{tabular}{|c|c|c|c|}
\hline 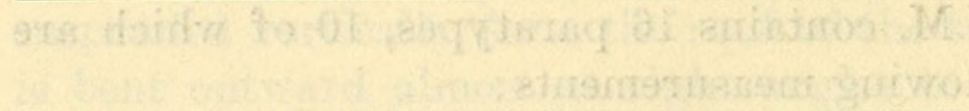 & $\begin{array}{l}\text { Number of } \\
\text { whorls }\end{array}$ & Length & Diameter \\
\hline 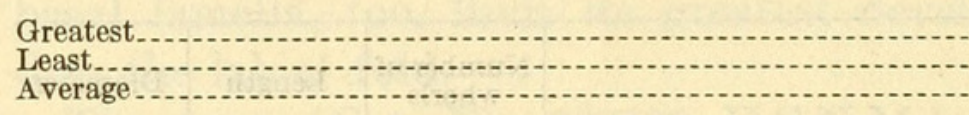 & $\begin{array}{l}16.2 \\
11.1 \\
14.2\end{array}$ & $\begin{array}{l}20.3 \\
12.1 \\
15.9\end{array}$ & $\begin{array}{l}4.5 \\
4.0 \\
4.4\end{array}$ \\
\hline
\end{tabular}

HOLOSPIRA (HOLOSPIRA) MITRAENSIS, new species

Plate 1, fig. 9

Shell cylindroid, white. The type, the only specimen before us, consists of almost the last five whorls. It is sufficiently peculiar to merit description. Whorls moderately rounded, marked by obsolete axial riblets which are a little more strongly developed on the last whorl than on the earlier ones, but even here they are very poorly expressed. Suture moderately constricted. Periphery well rounded. Base short, very strongly rounded, narrowly openly umbilicated, marked by the continuation of the axial riblets. The last whorl is solute and is marked by moderately closely spaced, rather irregular axial threads which encircle the whorls. There is also a strong angle present on this portion behind the posterior angle of the aperture and a less pronounced angle behind the junction of the columella and parietal wall. Aperture rather large, with a strongly expanded and reflected peristome. The internal axis is hollow, very narrow in the last whorl, and a little less so in the penultimate. A slender columnellar fold begins in the penultimate whorl and extends through the two whorls preceding this, reaching its highest development in the fourth to last turn where also the parietal and basal lamellae, which are almost confined to this turn, attain their highest development. Here, too, the slender labial fold is present.

The type (Cat. No. 363142 U.S.N.M.) was collected by C. R. Orcutt at La Mitra Mountain, Monterey, Nueva Leon, Mexico. Length, $8.9 \mathrm{~mm}$.; diameter, $3 \mathrm{~mm}$. 
This species strongly resembles Holospira (Holospira) topochicoana, distinguished from it at a glance, however, by its minute size.

\section{HOLOSPIRA (HOLOSPIRA) BACHIA, new species}

Plate 1, Fig. 10

Shell small, rather stout, cylindro-conic, pale brown with white ribs. Nuclear whorls 3, well rounded, forming an almost cylindrical spire which is truncated at the apex, all but the last half turn marked with fine granules only; the last half whorl is marked by somewhat irregular, poorly developed, axial riblets, which are much more distantly spaced than those on the postnuclear spire. The early whorls of the postnuclear spire are moderately rounded and form a rather long cone. They are marked by moderately, distantly spaced decidedly retractively slanting, somewhat sinuous axial riblets which increase in number and proximity as the whorls progress. On the middle whorls they are about as wide as the spaces that separate them and well developed. On the last turn they become less in number, wider spaced and stronger. Suture well impressed. Periphery of the last whorl well rounded. Base very short, strongly rounded, narrowly umbilicated, marked by the continuations of the ribs which extend into the umbilical chink. The last whorl is solute for a little distance. On this portion the axial riblets become much enfeebled, very closely spaced and encircle the entire whorl. Behind the posterior angle of the aperture is an obsolete keel. Aperture subtriangular; parietal wall somewhat curved, peristome expanded and slightly reflected. The internal pillar is moderately strong, hollow; in the last turn it is much more slender than in those preceding. The columellar fold begins on the last half of the last turn and reaches its maximum development in the penultimate whorl, where also the outcurved parietal fold and the basal fold, as well as the rather slight labial fold, reach their maximum development. None of these folds except the columellar twist extend posterior to the penultimate turn.

The type (Cat. No. 363152 U.S.N.M.) was collected by C. R. Orcutt in river drift near the Rio Balsas Station, Guerrero, Mexico. It has 13.1 whorls and measures-length, $12.7 \mathrm{~mm}$.; diameter, $4.3 \mathrm{~mm}$. Cat. No. 363153 U.S.N.M. contains three additional specimens which yield the following measurements:

\begin{tabular}{|c|c|c|c|}
\hline 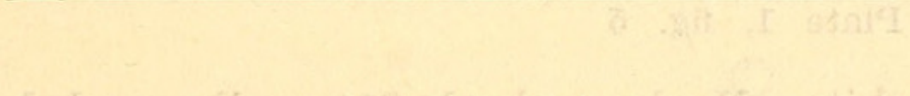 & $\begin{array}{c}\text { Number of } \\
\text { whorls }\end{array}$ & Length & Diameter \\
\hline $\begin{array}{l}\text { Greatest_. } \\
\text { Least_-_. } \\
\text { A verage }\end{array}$ & $\begin{array}{l}14.5 \\
13.1 \\
13.5\end{array}$ & $\begin{array}{l}14.7 \\
11.9 \\
13.3\end{array}$ & $\begin{array}{l}4.9 \\
3.5 \\
4.3\end{array}$ \\
\hline
\end{tabular}


HOLOSPIRA (HOLOSPIRA) PEDROANA, new species

\section{Plate 1, fig. 3}

Shell large, cylindro-conic, very pale brown, almost white. Nuclear whorls 2.5, well rounded, marked by very fine granules, forming a truncated cylindrical apex. Postnuclear whorls increasing slowly in size, well rounded, marked by very distantly spaced, low, rounded, retractively slanting axial ribs which are strongest on the early turns. On the middle turns they become almost obsolete and very far apart. On the last two whorls they again become stronger and on the last they are almost lamellar. The last whorl is decidely contracted toward the base. Suture well impressed. Periphery of the last whorl well rounded. Base rather short, narrowly umbilicated, marked by the continuations of the axial ribs. The last third of the last whorl is decidedly solute with a very strong angle behind the posterior angle of the aperture, and an obsolete angle behind the junction of the inner and parietal wall. The solute portion is marked by very irregular more or less fused axial riblets which encircle the whorls. Aperture subtriangular, parietal wall somewhat sinuous, peristome decidedly expanded and strongly reflected. The internal pillar is slender, somewhat twisted in the last turn and without columellar fold here. In the penultimate turn and the turn preceding this, a slender, columellar fold is apparent. In the antepenultimate whorl also the strongly outturned parietal wall is present and well developed. Here, too, a short basal fold is apparent, and a very weak labial fold is present in the narrow gap between the two.

The type (Cat. No. 362176 U.S.N.M.) was collected by C. R. Orcutt under agave in the hills north of San Pedro, San Luis Potosi, Mexico. It has 17.2 whorls and measures-length, $20.9 \mathrm{~mm}$.; diameter, $4.4 \mathrm{~mm}$.

Four paratypes (Cat. No. 362177 U.S.N.M.) yield the following measurements :

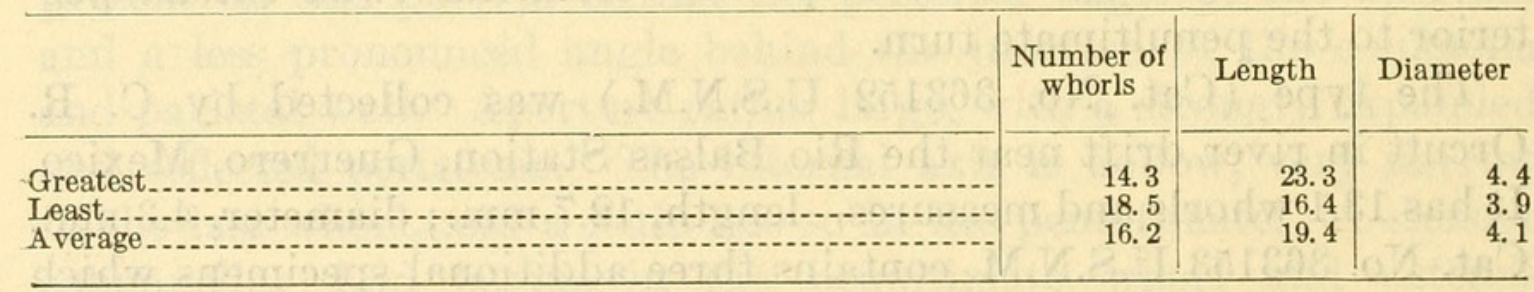

HOLOSPIRA (HOLOSPIRA) TOPOCHICOANA, new species

Plate 1, fig. 5

Shell rather large, milk white. Nuclear whorls $2 \frac{1}{2}$, well rounded, forming a narrow blunt cone. Postnuclear whorls flattened with the summit almost appressed, the first marked by rather strong retractively slanting distantly spaced axial riblets which be- 
come decidedly enfeebled on the next three turns, disappearing shortly thereafter. The middle whorls are smooth, excepting coarse incremental lines. On the last turn the riblets again become apparent and on the last portion of the last turn are very strong. Suture slighly impressed. Periphery of the last whorl broadly obtusely angulated. On the last whorl there is a constriction a little posterior to the periphery which becomes decidedly apparent as the whorls progress, so that the outer portion of the last whorl behind the aperture is decidely concave. The last whorl is solute at its extremity, bearing a conspicuous broad keel behind the posterior angle of the aperture. The solute portion is marked by numerous closely spaced riblets which appear like obsolete lamellae. Aperture subquadrate, the outer lip and parietal wall somewhat sinuous, peristome broadly expanded and reflected. The internal axis is moderately thick, hollow, decidedly contracted in the last whorl and a little less so in the penultimate. In the latter turn the columellar fold begins as a slender cord and reaches its greatest development in the whorl preceding this. Here, too, the outturned strong parietal lamella appears and disappears. The same holds true of the basal fold and the slender labial cord.

The type (Cat. No. 363143 U.S.N.M.) was collected by C. R. Orcutt at Topochico Mountain, Monterey, Nueva Leon, Mexico. It has 15.4 whorls and measures-length, $17.8 \mathrm{~mm}$; diameter, $4.5 \mathrm{~mm}$. Cat. No. 363144 U.S.N.M. contains five fragments of paratypes.

\section{EXPLANATION OF PLATES}

FIG. 1. Holospira (Coelostemma) adria.

2. Holospira (Bostrichocentrum) eurybia.

3. Holospira (Holospira) pedroana.

4. Holospira (Holospira) creightoni.

5. Holospira (Holospira) topochicoana.

6. Holospira (Bostrichocentrum) galathea.

7. Holospira (Holospira) alvarezensis.

8. Holospira (Holospira) andromeda.

9. Holospira (Holospira) mitraensis.

10. Holospira (Holospira) bachia.

11. Holospira (Tristemma) meiea.

12. Holospira (Coelostemma) iqualaensis.

13. Holospira (Holospira) amalthea.

14. Holospira (Coelostemma) adana.

15. Holospira (Tristemma) hyperia.

16. Holospira (Coelosiemma) balsasensis. 


\section{$2 \mathrm{BHL}$ Biodiversity Heritage Library}

Bartsch, Paul. 1926. "New urocoptid land shells from Mexico." Proceedings of the United States National Museum 70(2653), 1-13.

https://doi.org/10.5479/si.00963801.70-2653.1.

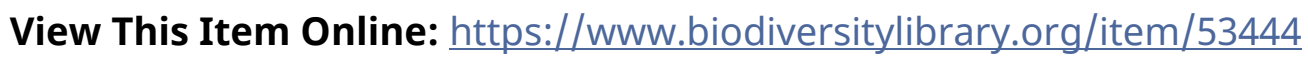

DOI: https://doi.org/10.5479/si.00963801.70-2653.1

Permalink: https://www.biodiversitylibrary.org/partpdf/52003

\section{Holding Institution}

Smithsonian Libraries

\section{Sponsored by}

Smithsonian

\section{Copyright \& Reuse}

Copyright Status: Public domain. The BHL considers that this work is no longer under copyright protection.

This document was created from content at the Biodiversity Heritage Library, the world's largest open access digital library for biodiversity literature and archives. Visit BHL at https://www.biodiversitylibrary.org. 